不変が多かった事実は，治療管理の不徹底を意味するも ので，患者に効しては入院治療の必要古考光る。また退 職後も多くは不変に経過しているが，排菌者がある事実 は，予防医学的には，乙れらの人々の感染源としての危 跧性については，充分考慮せねばならない。しかも，加 かる退職煋が中小企業に䔟り的くことは重大である。

\section{7. 結核患者家族に対する化学予防に関する研究}

渡辺正男（福息医大・衙生） 武田信子（福舄保健所）

目的：結核息者家族内発病防止のため，ヒドロンサン の服用効果を比較観察した。

方法：福島市内の 2 地区（渡利・清水）党選び，元の 肺結核患者を除く家族全員に対し，ヒドロンサン服用 (15 世帯59名）した群と対照として，グロンサン服用群（21 世帯86名）飞分け，前磁注年令別に服用量を定め，後群 屾一定量にし，各群とも 1 日おきに，6 力月間内服せし

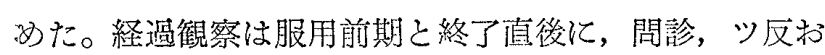
よび間接撮影 $(60 \mathrm{~mm})$ 党䒠施し各群を比較した。

結果：1）各群已も服用 6 力月後に新発生㭧者はなか った。2）前期に新発見された秘者はいずれも要観察者 で，ヒドロンサン服用群は 3 名, グロンサン服用群は 2 名で軽快率山前群がやや良好の傾向を示した。3) ッ反 の変動。陽転した者はグロンサン服用群に多く,ヒドロ ンサン服用群は陰転化の傾向を示した。

\section{8. 結核腫及び類結核腫㥞陰影に対する INAH 誘道 体投与の効果について}

阔田静雄（結核予防会大阪府支部）

1）対象：大阪市庘の商社，工場において，学研病型 C型であるが，单位病紧の大いさが $1 \mathrm{~cm}$ 越すもの， 末よび $1 \mathrm{~cm}$ 以上の結核腫学選んだ。

てのうち陰影のうすい桑かそうなものを，とくに CB

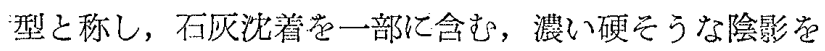

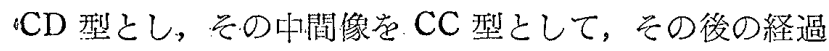
観察を行なった。

2) 方法: 䀡和 32 年 5 月より INHG，1日0.5g 学連 日，昭和34年12月まで 2 年半にわたって投宗した。

\section{3) 結諭}

A)種々のX線所見の変化が,最も多く見られたのはC B型で，57.1\% に見られた。乙れらは当然，化学療法 の段階にあるものと考觉られる。变化した恃期について 見ると，陰影加硬化型になるものは，ほとんど投与後 1 年以内であるが，陰影方消失して繊維像となり，あるい
は空洞化するものは 2 年〜 2 年半においても見られたて とは，かかる陰影に対しては，化学療法剂の投与が，か なり，长期にわたる必要があるてとを示している。

B）X線所見が不变になってから，INHG 者投与寸 るまでの期間苍検討すると，2 年以上X線所見が不変で あるものからでも，変化をきたすものが多く，Targetp oint の考元方に合後，一考䓰要すると思う。

C) 過去の化学潦法の期間の検討では, 経験のない者 に変化が多かったのは当然であるが，2年以上の経験者 からも変化するものがあるのは，当初の病巣，および化 学療法中止時のX線所見分大寸き影響をもっているとと 苯示している。

D) 結核䭪と類結核婳様陰影付対するINHGの効果は ほとんど同様であった。

E） CC 型以下では変化が少なく，再発防止のための 化学予防の対象は, ての群に求めるととが妥当ではない かと思われる。

149. 工場における結核管理に関する研究 (1. 化学療 法用による発病防止について)

松田 司 (川崎製鉄暮合工場)

抗結核珴による初発病並びに再発病防止については， その投与薬剂の種類，投与量，投与方法，期間等のほか心， 対象者の back ground factor 異なるので，彼我を 比較するととは困難であるが，效果のあるととは知られ ている。当所においても，䀦和31年より長期にわたり， 200 有余名の結核要管理者に抗結核剤を投与して, 発病 防止に関し，一知見を得たのでここに報告する次第であ る。

被検者には PAS 5g， あるいは INH 50，100，150 mg のそれぞれを単独に，または併用して，每日投与し た。被㭘者たる要管理者は扔括放自覚症なく，また追 求するに足る他覚所見もないものが多いので, 効果の判 定には，主としてX線像による病巣の変化に目標を置い た。

PAS $5 \mathrm{~g}$ および INH $50 \mathrm{mg}$ の单独並びにそれらの 昨用では，充分の效果が得られなかったが，PAS $5 \mathrm{~g}$ と INH $150 \mathrm{mg}$ との併用は著效惡認めた。これについで PAS $5 \mathrm{~g}$ と INH $100 \mathrm{mg}$ との併用, INH $150 \mathrm{mg}$ およ び 100mg の単独使用の順に有效であった。

この際，同時に，血液像预よび，二，三の尿検查を実 施したが著変は認められなかった。 